\title{
Microbiological and Sensory Profile of Soymilk Based Juice Treated with Liquid Extract of A. Danielli
}

\author{
Dauda A.O, Adegoke G.O.* \\ Department of Food Technology, University of Ibadan, Ibadan, Oyo State, Nigeria, West Africa \\ *Corresponding author: adegboladauda@yahoo.com
}

Received May 30, 2014; Revised October 01, 2014; Accepted October 08, 2014

\begin{abstract}
The microbiological and sensory profile soymilk-based juice treated with aqueous extract of Aframomum danielli $(1 \%-3 \%-\mathrm{w} / \mathrm{v})$ and stored at $27 \pm 2^{\circ} \mathrm{C}$ for twenty four weeks were examined. Synthetic additives/preservatives, which have been in use over the years, are more expensive and mostly imported with hard earned scarce foreign exchange. Adequate research work into the production and utilization of indigenous food additives on a large scale has not been undertaken in developing countries. This work was therefore planned to ascertain the usefulness of extracts of $A$. danielli, a local spice, in stabilizing the microbiological quality of soymilkbased juice. Standard methods were used for the production of juice samples from pineapple, orange, carrot and milk from soybeans. They were blended together in equal proportion and thereafter treated with A. danielli extract $(1.0 \%$ to $3.0 \%$ ) and stored at $27 \pm 2^{\circ} \mathrm{C}$ for twenty four weeks. Infrared spectrophotometer was used to identify functional groups in Aframomum danielli and hence the active components responsible for the stability of the juice. Standard AOAC method was used for microbiological analysis of treated and untreated samples. Consumer evaluation of juice samples was done using analysis of variance (ANOVA). Some of the active components of the spice identified are 4-amino-acetophenone, N,N-dimethyl-2-chloroacetoacetamide, 3-beta-acetoxy-5-etienic acid, 6,10dimethylundeca-5,9,-diene2-one, Phenyl-3-buten and 4-Phenyl butanone. There were significant differences in the microbial counts of the treated and untreated samples. Treated samples experienced little or no growth over the period of storage. The results validate previous reports that $A$. danielli extract has great preservative potentials. There were significant differences $(\mathrm{P}<0.5)$ for colour and overall acceptability of the samples. When A. danielli extract was added to soymilk-based fruit juice, the microbiological and sensory qualities were found to be better preserved than that of the untreated samples.
\end{abstract}

Keywords: A. danielli, Soymilk-Based Juice, Microbial load, Shelf Life

Cite This Article: Dauda A.O, and Adegoke G.O., "Microbiological and Sensory Profile of Soymilk Based Juice Treated with Liquid Extract of A. Danielli." American Journal of Food Science and Technology, vol. 2, no. 5 (2014): 145-149. doi: 10.12691/ajfst-2-5-2.

\section{Introduction}

Fruits and vegetables are among the most important foods of mankind as they are not only nutritive but are also indispensible for the maintenance of health. They play important roles in the diet of most people in the tropics, providing essential minerals and vitamins and adding colour, flavour and variety to monotonous diets. Fruits and vegetables, in particular, are abundant sources of carotenoids in the diet and are highly perishable subject to rapid deterioration by microorganisms, enzymes, or oxidation reactions. Delgado and Sun (2000) reported the combination of freezing technology's beneficial effects of low temperature at which microorganisms cannot grow, reduced chemical reactions, and cellular metabolic reactions are delayed to retain the sensory attributes and nutritional properties of the products. They deteriorate more under tropical conditions due to the high ambient temperatures and humidity, pest and disease infestations, poor handling and storage facilities (Levi et al, 1983;
Aworh and Olorunda, 1988). This has led to large post harvest losses during the period of abundance, followed by season of scarcity. Fruits and vegetables are essential component of a healthy diet, able to decrease the risk of cardiovascular diseases and cancer (Allende et al, 2006). Apart from their nutritional and sensory properties, they are currently recognized as active and protective agents (Olivas and Barbosa-Canovas, 2005). Fruits and vegetables contain a wide variety of potential cancer inhibitory nutrients and other phytochemicals. Substantial evidence has indicated a biological link between dietary constituent and carcinogenesis (Clade, 1999; Steinmetz et al., 1996).

Many fruits and vegetables are subjected to various types of processing prior to consumption. They may be canned, dried or processed into juices. Processed products are expected to be essentially uniform in composition and sensory characteristics from batch to batch. Juice processing is one of the attractive and effective means of fruit utilization and preservation. Fruit juices are becoming an important part of the modern diet in many communities (Ghengbesh et al., 2005). Fruit juice with 
soya, tea, milk or vegetables, with the addition of functional ingredients such as L-carnitine and vitamins, offer a wide variety of alternative in terms of product and positioning, from low-calorie to free of refined sugars, from wellness to fitness. Currently, the market demand for tropical fruit juices are increasing tremendously due to increase in consumer awareness that fruit juices are healthy and nutritious in such a way that they can beneficially affect human health (Wong et al., 2003). In line with this, consumers are also becoming more sensitive and vigilant on the use of synthetic additives to preserve food safety or enhance characteristics such as colour and flavour (Corbo. 2009).

Various preservative methods have been adopted in extending the shelf life of fruit juices including the use of spices. In recent times, spice antioxidants have raised considerable interest among food scientists, manufacturers, and consumers, because of their natural antioxidants ( $\mathrm{Lu}$ et al., 2011). Many synthetic chemicals such as butylated hydroxyl anisole (BHA) and butylated hydroxyl toluene (BHT), though very effective as antioxidants, have been known to have toxic and carcinogenic effects on humans (Ito et al., 1985). Synthetic antioxidants may result in liver swelling and influence liver enzyme activities (Martin and Gilbert, 1968). Numerous studies have shown the antioxidant potentials of aromatic, spicy, medicinal plants (Chang et al., 1977; Osawa et al., 1992; Weng and Gordon, 1992). The use of these plant materials as natural antioxidants for food, cosmetics and other application becomes necessary because of food safety issues. Because of their natural nature and their scavenging properties, they are more readily accepted by consumers (Miliauskas et al., 2004; Miliauskas et al., 2004). Consumers are increasingly aware of the risk posed by synthetic antioxidants due to their high volatility and instability at elevated temperatures. As a result of this, focus has been shifted to the use of natural antioxidants in food preservation (Odukoya et al., 2005; Oboh and Rochas, 2007; Adefegha and Oboh, 2011a).

Report has it that the main active components in spices are phenol acids, flavonoids and volatiles or essential oils (Shan et al., 2005; Wojdylo et al., 2007; Viuda-Martos et al., 2011; Lu et al., 2011). Consumption of antioxidant rich food such as spices, fruits, and vegetables could be a practical approach towards improving antioxidant status, thereby enhancing good health and preventing diseases (Chu et al., 2002; Oboh and Rochas, 2007; Carlsen et al., 2010). Some natural spices, herbs and flavour are known to inhibit oxidation and have been proposed for use in foods. Aframomum danielli is one of these numerous spices and is known to possess preservative properties (Adegoke et al., 2002) and has among other characteristics, nutritive and broad antimicrobial effect (Adegoke and Skura, 1994). Antioxidant extracts are more potent than synthetic antioxidants like butylated hydroxytoluene (BHT) and butylated hydroxianisole (BHA) (Adegoke and Copalakrishna, 1998) with potent synergistic inhibitory effects on food spoilage yeast when used in combination with hydrostatic pressure (Adegoke et al., 1997).

Soymilk (also called soyamilk, or soybean juice and sometimes referred to as soydrink/beverage) is a beverage made from soybeans (Glycine max). It is a stable emulsion of oil, water, and protein. Soymilk is produced by soaking dry soybeans and grinding with water using Hammer mill before cooking at boiling point for about 20 minutes. Soymilk contains similar proportion of protein as cow's milk; around $3.5 \%$ and $2 \%$ fat, $2.9 \%$ carbohydrate, and $0.5 \%$ ash. They have been blended with other food products to produce other products, most likely, with better nutritional qualities. Milk-based products all contain actual milk (and/or soymilk) or different combinations of modified proteins. Most of the popular milk-based beverages are good sources of protein, containing 10 to 40 grammes per serving.

As a result of this, new innovation/technology must be applied in the production of better quality products. The main requirement new technology must meet is to ensure product microbial safety while preserving sensory and nutritional characteristics to obtain products more similar to fresh foods (Torres and Velazquez, 2005). Producers equally face the challenge of always finding ways to preserve food in a high quality state until it reaches the consumers. The present study was carried out to investigate the effect of $A$. danielli liquid extract, a local spice, on the microbiological and sensory profile of soymilk-based juice with regard to the reported polyfunctional nature of the spice.

\section{Materials and Methods}

A. danielli pods were purchased from Oja-Oba and Bode, two local markets in Ibadan. The seeds were removed, cleaned of extraneous materials, winnowed and milled into powder using hammer mill. The powder was then sieved with a wire mesh to obtain fine powder. $1 \mathrm{~g}, 2 \mathrm{~g}$ and $3 g$ respectively of the powder were each added to $100 \mathrm{mls}$ of distilled water and mixed thoroughly at $-4 \pm 2^{\circ} \mathrm{C}$ for 5 days before being centrifuged at 300 revolutions per minute for 20 minutes. The supernatants were obtained as A. danielli extract (Adegoke and Skura, 1994).

\subsection{Juice Preparation}

Fresh oranges, pineapple were obtained from a farm at Ajibode village in Ibadan. Carrots were purchased from Sabo in Ibadan, while soybean was sourced from International Institute for Tropical Agriculture (IITA) in Ibadan. Fresh juicy, good quality fruits and vegetable to be used for the research were sorted for processing. The fruits and vegetable were thoroughly washed under tap water to remove extraneous materials before juice was extracted from them using a modified method of Battcock et al., 1998. Soymilk was equally made from the cleaned soybeans under laboratory condition. Equal quantities each of the juice from orange, pineapple, carrot and laboratory prepared soymilk were blended together. The blended juice was then treated with aqueous extract of $A$. danielli $(1 \%-3 \%-\mathrm{w} / \mathrm{v})$ and stored in plastic polyethylene containers at $27 \pm 2^{\circ} \mathrm{C}$ for twenty four weeks with the untreated samples.

\subsection{Microbiological Analysis}

Pour plate technique was used for the microbiological examination of the various samples as described by Adegoke (2000). One gramme of each of the sample was dissolved in $1 \mathrm{ml}$ of $2 \%$ sterile sodium citrate solution in order to prepare a suspension. $1 \mathrm{ml}$ of the suspension was 
then used for serial dilution of between $10^{-1}$ to $10^{-6} .1 \mathrm{ml}$ of diluted sample was placed in sterile disposable petridishes (sterilin) in triplicates. At about $44^{\circ} \mathrm{C}-50^{\circ} \mathrm{C}$, the various media were poured on to the samples in the petridishes and allowed to set, inverted and incubated for 48hours.

\subsection{Sensory Evaluation}

Sensory evaluation of the juice was judged for color, flavour, taste and general acceptability on a nine-point hedonic scale, varying from 'dislike extremely' (score1) to 'like extremely' (score 9) was used, according to a modified method of Stone and Sidel (1992). An informal panel of 10 untrained assessors carried out the sensory evaluation. The juice was served in a transparent white glass cups for proper assessment. Twelve (12) cups with three (3) cups each representing each treatment and coded separately in order to have a mean score of each treatment

\section{Results and Discussion}

\subsection{Microbial Analysis}

Table 1 gave the result of the microbial and mould analysis carried out on the samples. Bacterial and mould counts for untreated samples recorded high values after twenty four weeks of storage (not shown in the table). The untreated samples recorded high loads for both the mould and bacterial counts, while over half of the treated samples recorded little or no growth after the twenty four weeks of storage (table 1).

Min et al (2003a, 2003b) achieved a 6 log inactivation of endogenous bacteria in tomato and orange juices after thermal (90C, 90s) and Pulse Electric Field (PEF) treatment ( $40 \mathrm{KV} / \mathrm{CM}, 5757 \mathrm{us}$ and $\left.45^{\circ} \mathrm{C}\right)$. The shelf life of the treated samples was established taking into consideration the initial microbial population of the untreated samples. The lethal effects of $A$. danielli extract on some microorganisms or the decrease in the amount of organisms in A. danielli treated samples could be attributed to antimicrobial effect of A danielli as reported in previous research works by Zaika, 1988; Adegoke and Skura, 1994; Fasoyiro et al., 2001. Likewise, Ogunwolu and Adio (2003) found $A$. danielli extract to be as effective as sodium benzoate in the reduction of microbial count and subsequent preservation of cashew juice. Similar effect of $A$. danielli on products was obtained in this study.

Some researchers have equally used synthetic and/or natural additives in preventing microbial deterioration in foods. Lavinas et al., (2008) reported that the quality of juice sample was stable for 8 weeks when treated at high hydrostatic pressure of $400 \mathrm{MPa}$ for 3 minutes at $25^{\circ} \mathrm{C}$ under refrigeration; Ashaye et al, (2007) reported a reduction in microbial count and resultant preservation of cheese when treated with A. danielli extract. Ceylan et al (2004) was able to reduce the population of $E$. Coli (0157:H7) from $5.31 \mathrm{CFu} / \mathrm{ml}$ to 2.2 in 3 days in apple juice that was treated with potassium sorbate. Likewise, Crook and Boylston (2004) reported that $0.1 \%$ potassium sorbate was able to prevent deterioration in apple cider during storage, Luedtke and Powell (2002) reported increased shelf life of juice by inhibiting yeast and mould in a low $\mathrm{pH}$ environment using potassium sorbate, while Hussain et al (2008) used $0.2 \%$ potassium sorbate to preserve apple and apricot juice blends.

Omemu et al (2006) reported high microbial load in locally prepared roselle juice hawked daily in our local markets, Al-Jedah and Robinson (2002) reported high microbial load (1.4-3.2 X 10 ${ }^{8}$ ) for juices sold in Qatar, while Gbenghesh et al (2005) reported 1.8-8.4 X $10^{6}$ for various single strength juices sold in Tripoli, Libya. On yeast and mould counts, Omemu et al., (2006) reported $1.2 \times 10^{4}$ in fresh fruit juices, while 1.0-3.3 X $10^{4}$ was reported in fresh fruit juices sold in Qatar (Al-Jedah and Robinsin, 2002).

There were reductions in the microbial populations of the treated samples when compared with those of the untreated samples. The reduction experienced could be attributed to the potency of $A$. danielli extract which could be compared to that reported for other modes of treatments such as the use of PEF reported by Jia et al., 1999; Yeom et al., 2000; Elez et al., 2006; Rivas et al., 2006 in extending the shelf life of the products and even better, as local spice in this case $A$. danielli, has no reported or recorded side effect on consumers or quality of the products, most especially now that most of the synthetic preservatives in use come with their attendant problems. It was observed that the quality of the juice was stable for over 10 weeks and that bacteria and mould load increases afterwards, which might be due to the germination of spores as the effect of the preservatives decreases gradually or could be as a result of the presence of natural microorganisms in A. danielli extract that are present in the unpurified spice.

Table 1. Microbiological Quality of the Preserved Blend of Juice from Carrot, pineapple, orange with Soymilk

\begin{tabular}{|c|c|c|}
\hline No. of Wks. & Bacteria (CFU/ml x $10^{-3}$ & Moulds (CFU $/ \mathrm{ml} \mathrm{x} 10^{-3}$ ) \\
\hline 2 & Nil & $\mathrm{N}$ \\
\hline 4 & Nil & $\begin{array}{c}\text { il } \\
\mathrm{Ni}\end{array}$ \\
\hline 6 & Nil & $\begin{array}{c}\mathrm{l} \\
\mathrm{Ni}\end{array}$ \\
\hline 8 & Nil & $\begin{array}{c}\mathrm{l} \\
\mathrm{Ni}\end{array}$ \\
\hline 10 & Nil & $\begin{array}{c}\mathrm{l} \\
\mathrm{Ni}\end{array}$ \\
\hline 12 & Nil & $\begin{array}{c}\mathrm{l} \\
\mathrm{Ni}\end{array}$ \\
\hline 14 & Nil & $\begin{array}{c}\mathrm{l} \\
\mathrm{Ni}\end{array}$ \\
\hline 16 & $<1$ & $\begin{array}{c}\mathrm{l} \\
\mathrm{Ni}\end{array}$ \\
\hline 18 & $<1$ & $\begin{array}{c}1 \\
\text { Nil }\end{array}$ \\
\hline 20 & $<1$ & $<1$ \\
\hline 22 & $<1$ & $<5$ \\
\hline 24 & $<5$ & $<5$ \\
\hline
\end{tabular}

Sensory analysis: There were significant differences in the colour and general acceptability of the samples. The result from the sensory evaluation demonstrated that the use of $A$. danielli in soymilk-based juice did not have any negative effect on sensory quality attributes. After about three and half months of storage, the taste and colour of the treated samples began to depreciate and did not have much effect on other quality attributes of the juice. There were no significant differences in the taste and aroma of both the untreated and treated samples as shown in table 2 . The overall acceptability assessment for the juice was put at liked moderately. 
Table 2. Mean Scores of Sensory Acceptance of CPOS Juice

\begin{tabular}{|c|c|c|c|c|}
\hline Sample & Colour/App & Taste & Aroma/Flavour & $\begin{array}{c}\text { Acceptability } \\
\text { Overall }\end{array}$ \\
\hline Untreated & $6.07^{\mathrm{a}}$ & $6.17^{\mathrm{a}}$ & $5.83^{\mathrm{a}}$ & $5.97 \mathrm{~b}$ \\
\hline A1 & $5.83^{\mathrm{c}}$ & $6.20^{\mathrm{a}}$ & $6.20^{\mathrm{a}}$ & $6.10^{\mathrm{a}}$ \\
\hline A2 & $5.97^{\mathrm{b}}$ & $5.77^{\mathrm{a}}$ & $5.87^{\mathrm{a}}$ & $5.93^{\mathrm{b}}$ \\
\hline A3 & $6.07^{\mathrm{a}}$ & $5.80^{\mathrm{a}}$ & $5.87^{\mathrm{a}}$ & $5.57^{\mathrm{c}}$ \\
\hline
\end{tabular}

${ }^{*}$ CPOS- Blend of carrot, pineapple, orange and soymilk.

*A1-Sample treated with $1 \%$ A. danielli extract.

*A2-Sample treated with $2 \%$ A. danielli extract.

*A3-Sample treated with 3\% A. danielli extract.

*Mean + SD down a column with superscript are significantly different

with $\mathrm{a}>\mathrm{b}>\mathrm{c}$. Mean separation done with Duncan Multiple Test Range.

*Means for each attributes followed by the same letter are not

significantly different at $5 \%$ level by Turkey.

\section{Conclusion}

This study has been able to highlight once again the preservative potentials of A.danielli extract on soymilkbased juice for up to three and half months. Aframomum danielli was efficient in decreasing or preventing the growth of micro organisms over the period of storage. The juice was also accepted in terms of sensory attributes. The indigenous spice is cheap and easily accessible thus leading to a reduction in the cost of production on a large scale. The utilization of this spice should be encouraged and recommended to people as healthy drink.

\section{References}

[1] Adegoke, G.O (2000): Understanding Food Microbiology. First Edition, Shalom Prints, Ibadan. Pg. 49-65.

[2] Adegoke, G.O.; Gbadamosi, R; Evwoerhuhoma, F; Uzo-Peters, P.I; Falade, K.O, Itiola, 0: Moody, 0 and Skura, B. (2002): protection of Maize (Zeamays) and Soyabean (Glycinemax) using Aframomum danielli. European Food Research and Technol. 214, 408-411.

[3] Adegoke, G.O, Iwahashi, H. Komatsu, Y. (1997): Inhibition of Saccharomyces cerevisae by combination of hydrostatic pressure and monoterpenes. J. Food Science 67: 404-405.

[4] Adegoke, G.O; Gopalakrishna, A.G. (1998): Extraction and identification of antiodixants from the spice Aframomum danielli. J. Am. Oil Chern. Soc. 75: 1047-1052.

[5] Adefegha SA, Oboh G (2011a). Enhancement of Total Phenolics and Antioxidant Properties of Some Tropical Green Leafy Vegetables by Steam Cooking. J. Food Process Preserv. 35 (5): 615-622.

[6] Adegoke, G.O. Skura, B.J. (1994); Nutritional, Profile and Antimicrobial Spectrum of the spice Aframomum danielli, plant food Human Nut. 45: 175-182.

[7] Al-Jedah and J.H. and Robinson RK (2002). Nutritional Value and Microbiological Safety of Fresh Juices sold through Retail Outlets in Qatar. Pakistan Journal of Nutritional 1: 79-81.

[8] Allende A. Tomas-Barberan FA, Gil MI. Minimal processing for healthy traditional foods. Trends in Food Science and Technology. 2006; 17: 513-519.

[9] AOAC (2005): Official Methods of Analysis of Association of Official Analytical Chemist International, Washington (D.C.).

[10] Ashaye A.O., Taiwo OO and Adegoke GO (2007). Effect of Local Preservative (Aframonium danieli) on the Chemical and Sensory Properties of Stored "warankassi” African Journal of Agricultural Research 1: 010-016.

[11] Aworh, O.C. and Olorunda, A.O. (1988). Packaging and Storing Technology of fresh fruits and vegetables with special references to tropical conditions. Proc. National Workshop on Improved Packaging and Storage system for fruits and vegetables in Nigeria. Pg. 75-91.

[12] Battcock M, Axain-Ali S, Axtell B and Fellow PI (1998). Successful Approaches to Training in Food Processing. IT Publications, pg B6.
[13] Ceylan E, Fung DYC Sabah J.R. (2004). Antimicrobial Activity and Synergistic Effect of Cinammon with Sodium Benzoate or Potassium Sorbate in Controlling Eschenchia coli 0157: H7 in Apple Juice. Journal of Food Science 69: 102-105.

[14] Chang SS, Ostic-Matijasevic BO, Hsieh QA and Huang CL (1977). Natural antioxidant from rosemary and sage. J. Food Sci., 42: 1102-1106.

[15] Clade MI (1997). Food Nutrition and the Prevention of Cancer; a global perspective, American Institute for Cancer Research/World Cancer Research Fund; 15: 523-6.

[16] Corbo MR, Bevilacqua A. Campaniello D, D’Amato D, Speranza B. Sinigaglia M. Prolonging microbial shelf life of foods through the use of natural compounds and non-thermal approaches- a review. International Journal of Food Science and Technology, 2009; 44: 223-241.

[17] Crook L.R. and Boylston T.D. (2004). Flavour Characteristics of Irradiated Apple Cider during Storage: Effect of Packaging Materials and Sorbate Addition. Journal of Food Science 69: 557562.

[18] Delgado AE, and Sun DW (2000). Heat and mass transfer for predicting freezing processes, a review. Journal of Food Engineering, 47: 157-174.

[19] Elez P, Soliva RC, Martins O. 2006. Comparative study on shelf life of orange juice processed by high intensity pulsed electric fields or heat treatment. Euro Food Res Technol 222: 321-9.

[20] Fasoyiro, S.B. Adegoke, G.O., Ashaye, O.A. Obatolu, V.A. and Owolade, O.F. 2001. Antimicrobial Characteristics of Aframomum danielli spice on Escherichia coli and Staphylococcus aureus. Moor Journal of Agricultural Research. 2: 159-161.

[21] Ghenghesh, K.S. Khalifa B., El-Ammin, W. Saleha, E. and Zalmum, A. 2005. Microbiological quality of fruit juices sold in Tripoli-Libya. Food control. 15: 855-858.

[22] Hussain I., A, Shakir I, A (2008): Combine Effect of Potassium Sorbate and Soduim Benzoate on Individual and Blended Juices of Apricot and Apple Juices grown in Azad Jammu and Kashmir. Pakistan Journal of Nutrition 7: 181-185.

[23] Ito N, Fukushima S, Hasegawa A, Shibata M and Ogiso T (1985). Carcinigenicity of butylated hydroxylanisole in F344 rats. J. Natl. Cancer Inter., 70: 343-347.

[24] Jia M., Zhang QH, Min DB. 1999, Pulsed Electric Field Processing Effects on Flavour Compounds and Micro-organism of Orange Juice. Food Chem 65: 445-51. Netherlands.

[25] Lavinas FC, Miguel MA, Lopes ML, Valente-Mesquita VL (2008). Effect of high hydrostatic pressure on cashew apple (Anacardium occidentale L.) juice preservation. J. Food Sci. 73: 273-277.

[26] Levi, A; Gagel, S. and Juven, B. (1983): Intermediate moisture tropical fruit products for developing countries. 1. Technological data on papaya. J. Food Tech. 18 (6): 667-685.

[27] Lu M, Yuan B, Zeng M, Chen (2011). Antioxidant Capacity and Major Phenolic Compounds of Spices Commonly Consumed in China. Food Res. Int. 44: 530-536.

[28] Luedtke AN and Powell DA (2002). A Review of North American Apple Cider Association in Eschenchia coli 0157: H7 outbreaks. Dairy Food Environment Sanitation 22: 590-598.

[29] Martin AD and Gilbert D (1968). Enzyme changes accompanying liver enlargement in rats treated with 3-tert-butyl-4hydroxyanisole. Biochem J. 10: 22-27.

[30] Miliauskas G, Venskutonic P, and van Beek TA (2004). Screening of radical scavenging activity of some medicinal and aromatic plants extracts. Food Chem., 82: 231-237.

[31] Miliauskas G, Venskutonis PR, and van Beek TA (2004). Screening of radical scavenging activity of some medicinal plant and aromatic plants extracts. Food Chem., 85: 231-237.

[32] Min S, Jin T, Zhang QH. 2003b. Commercial scale pulsed electric field processing of tomato juice. J Agric Food Chem 51: 3338-44.

[33] Min S, Jin ZT, Min SK, Yeom H, Zhang QH. 2003a. Commercialscale pulsed electric field processing of orange juice. J Food Sci 68 (4): $1265-71$

[34] Oboh G, Rocha JBT (2007). Antioxidant in Foods: A New Challenge for Food Processors. Leading Edge Antioxidants Research, Nova Science Publishers Inc. New York US, 35-64.

[35] Odukoya AO, Ilori OO, Sofidiya MO, Aniunoh OA, Lawal BM, Tade IO (2005). Antioxidant Activity of Nigerian Dietary Spices. Electr. J. Environ. Agric Food Chem. 4 (6): 1086-1093.

[36] Ogunwolu, S.O. and Adio, S.O. 2003. Preservative effect of A. danielli on the storage stability of cashew juice. Proceeding of the $27^{\text {th }}$ annual conference of Nigerian Institute of Food Science and 
Technology (NIFST). 13-17 $7^{\text {th }}$ Oct. held in Kano, Nigeria. Uzochukwu, E. Ed.

[37] Olivas GI, Barbosa-Canovas GV. Edible coatings for fresh-cut fruits. Critical Reviews in Food Science and Nutrition. 2005;45: $657-663$.

[38] Omemu AM, Edema M.O., Atayese A.O. and Obadina A.O. (2006). A Survey of the Microflora of Roselle (Hibiscus sabdariffa) and the resulting "Zobo" Juice. African Journal of Biotechnology. 3: 254-259.

[39] Osawa T, Hirotak K, Hahiwara H and Shibamoto T (1992). A novel antioxidant isolated from young green barley leaves. J. Agric. Food Chem., 1135-1138.

[40] Rivas A, Rodrigo D, Martinez A, Barbosa-Canovas GV, Rodrigo M. 2006. Effect of PEF and heat pasteurization on the physicochemical characteristics of blended orange and carrot juice. Lebensm Wiss Technol 39: 1163-70.

[41] Shan B, Cai YZ, Sun M and Corke H (2005). Antioxidant Capacity of 26 Spice Extracts and Characterization of their Phenolic Constituents. J. Agric. Food Chem. 53 (20): 7749-7759.

[42] Steinmetz KA, Potter ID (1996). Vegetables, fruits, and cancer prevention: a review. J AM Diet Assoc. 96: 1027-39.

[43] Stone H, Sidel JL (1992). Sensory evaluation practices. $2^{\text {nd }}$ ed. San Diego: Elsevier, pp. 336.
[44] Torres JA, Velazquez G (2005). Commercial opportunities and research challenges in the high pressure processing of foods. Journal of food Enhineering, 67, pp. 95-112.

[45] Viuda-Martos M, Ruiz-Navajas Y, Fernandez-Lopez J, PerezAlvarez JA (2011). Spices as Functional Foods. Crit. Rev. Food Science Food Saf. 51: 13-28.

[46] Weng XC and Gordon MH (1992). Antioxidant activity of quinines extracted from tanshen (Salvia mitorrhiza Bunge). J. Agric. Food Chem., 40: 1331-1336.

[47] Wong, P. Yusof S. Ghazali, H.M. and Cheman. Y.B. 2003.Optimization of hot water extraction of roselle juice using response surface methodology: a comparative study with other extraction methods. Journal of Science of Food and Agriculture 83: 1273-1278.

[48] Wojdylo A, Oszmianski J, Czemerys R (2007). Antioxidant activity and Phenolics Compounds in 32 Selected Herbs. Food Chem. 105 (3): 940-949.

[49] Yeom HW, Streaker CB, Zhang QH, Min DB. 2000. Effects of pulsed electric fields on the quality of orange juice and comparism with heat pasteurization. J Agric Food Chem 48: 4597-605.

[50] Zaika, L.L. 1988. Spices and Herbs: their antimicrobial activity and its determination. Journal of Food Safety 9: 97-117. 